\title{
Carotid sinus hypersensitivity in patients presenting with syncope
}

\author{
A. B. DAVIES, M. R. STEPHENS, AND A. G. DAVIES \\ From the Department of Cardiology, University Hospital of Wales, Cardiff; the Department of Medicine, \\ Bronglais Hospital, Aberyswyth, Dyfed, Wales
}

SUMMARY In 23 patients (ages 44 to 81 ) presenting with syncope, vertigo, or transient amnesia, carotid sinus massage produced a significant bradycardia in association with symptoms. The 10 most severely symptomatic patients were studied electrophysiologically, including measurement of intracardiac conduction times and corrected sinus node recovery times, as well as with carotid sinus massage before and after atropine. The only detectable abnormality in five of this group was asystole produced by carotid sinus massage; the other five had, in addition, evidence of either sinuatrial disease or an intracardiac conduction defect. Cardiac pacing in these 10 patients completely abolished their symptoms. In a control group of 52 asymptomatic patients (ages 36 to 87), an abnormal response to carotid sinus massage was uncommon $(2 \%)$.

Syncope, vertigo, and transient amnesia are common clinical problems and may result from many different conditions. Recently, it has been recognised that in some patients presenting with these symptoms an underlying arrythmia may be the primary cause (Abdon and Malmcrona, 1975). The carotid sinus syndrome is a rare cause of symptoms in association with transient bradycardias (Weiss and Baker, 1933; Ferris et al., 1935).

In patients presenting with idiopathic syncope, carotid sinus massage may induce severe bradycardia. We report on a study of such a group of patients, in whom intracardiac electrophysiological tests were performed during carotid sinus massage.

\section{Patients and methods}

\section{(1) CONTROL GROUP}

The response of heart rate to carotid sinus massage was assessed in a control group of 52 men in hospital (ages 36 to 87). They were in sinus rhythm, with no evidence of cardiac or neurological disease and had normal resting electrocardiograms. None had suffered from syncope or disturbance of consciousness or other symptoms related to the central nervous or cardiovascular systems.

\section{(2) SYMPTOMATIC GROUP}

Over an 18-month period, 23 patients $(15 \mathrm{men}$, eight women) referred for evaluation of syncope, near syncope, or transient amnesia (Table 1) had an

Received for publication 28 June 1979 abnormal response to carotid sinus massage, and they have been followed up over a period of 18 months to three years. All patients had a full history taken, clinical examination, and resting electrocardiogram. Carotid sinus massage was performed by the same observer in all cases, with the patient in a semirecumbent position of 45 degrees. Continuous electrocardiographic monitoring was carried out while the carotid sinus was massaged for five seconds unless asystole with symptoms intervened. All drug treatment had been withdrawn for at least 48 hours before this manoeuvre. None had been receiving digitalis or beta-blocking agents before study. An abnormal response was considered to be present if asystole occurred for more than three seconds (Thormann and Schwartz, 1975; Scarpa, 1976).

Intraventricular conduction disturbances were diagnosed from the electrocardiogram, using the criteria of Rosenbaum (1970). Ten severely symptomatic patients were submitted to electrophysiological studies which included measurement of intraventricular conduction times and measurement of corrected sinus node recovery times after atrial pacing at various rates (Narula et al., 1972). Carotid sinus massage was also performed and all measurements were then repeated after the intravenous administration of $1.2 \mathrm{mg}$ atropine.

\section{Results}

(1) CONTROL GROUP

In these 52 patients carotid sinus massage produced slowing of the sinus rate. The maximal $R R$ 
Table 1 Patients with abnormal response to carotid sinus massage; cases 1 to 10 studied electrophysiologically and paced permanently

\begin{tabular}{|c|c|c|c|c|}
\hline $\begin{array}{l}\text { Case } \\
\text { no. }\end{array}$ & $\begin{array}{c}\text { Age } \\
(y)\end{array}$ & Symptoms & $\begin{array}{l}\text { Associated } \\
\text { diseases }\end{array}$ & Electrocardiogram \\
\hline 1 & 67 & Syncope 1 month & Hypertension & Normal \\
\hline 2 & 73 & Syncope 6 months & Nil & $\begin{array}{l}\text { Sinus bradycardia/ } \\
\text { SA block }\end{array}$ \\
\hline 3 & 49 & $\begin{array}{l}\text { Syncope/amnesia } \\
8 \text { years }\end{array}$ & $\begin{array}{l}\text { Coronary } \\
\text { artery disease }\end{array}$ & Normal \\
\hline 4 & 52 & $\begin{array}{l}\text { Syncope/amnesia } \\
3 \text { months }\end{array}$ & $\begin{array}{l}\text { Coronary } \\
\text { artery disease }\end{array}$ & Normal \\
\hline 5 & 55 & Syncope 2 years & Hypertension & Left axis \\
\hline 6 & 64 & $\begin{array}{l}\text { Syncope/light- } \\
\text { headedness } \\
6 \text { months }\end{array}$ & $\begin{array}{l}\text { Coronary } \\
\text { artery disease }\end{array}$ & Normal \\
\hline 7 & 69 & $\begin{array}{l}\text { Syncope/amnesia } \\
2 \text { years }\end{array}$ & Nil & Normal \\
\hline 8 & 66 & Syncope 1 year & $\begin{array}{c}\text { Coronary } \\
\text { artery } \\
\text { disease; } \\
\text { diabetes }\end{array}$ & $\begin{array}{l}\text { Intermittent lt axis } \\
\text { SA block }\end{array}$ \\
\hline 9 & 71 & Amnesia 2 years & Nil & Intermittent LBBE \\
\hline 10 & 66 & Amnesia 10 years & Hypertension & Left axis \\
\hline 11 & 60 & Syncope 30 years & Hypertension & Left axis \\
\hline 12 & 54 & $\begin{array}{l}\text { Syncope } \\
18 \text { months }\end{array}$ & $\begin{array}{c}\text { Coronary } \\
\text { artery disease }\end{array}$ & Normal \\
\hline 13 & 47 & Light-headedness & Nil & Normal \\
\hline 14 & 64 & $\begin{array}{l}\text { Amnesic episodes } \\
1 \text { year }\end{array}$ & Nil & Normal \\
\hline 15 & 67 & $\begin{array}{l}\text { Syncope/vertigo } \\
1 \text { year }\end{array}$ & Nil & Normal \\
\hline 16 & 67 & Vertigo & Hypertension & Normal \\
\hline 17 & 66 & Vertigo & $\begin{array}{l}\text { Coronary } \\
\text { artery disease }\end{array}$ & Intermittent RBBE \\
\hline 18 & 82 & Syncope 2 years & Hypertension & Normal \\
\hline 19 & 44 & $\begin{array}{l}\text { Syncope/vertigo } \\
3 \text { years }\end{array}$ & $\mathrm{Nil}$ & RAD \\
\hline 20 & 63 & Syncope 1 year & $\begin{array}{l}\text { Cerebrovascu- } \\
\text { lar disease }\end{array}$ & $\begin{array}{l}\text { Intermittent atrial } \\
\text { fib }\end{array}$ \\
\hline 21 & 74 & Syncope 6 months & $\begin{array}{l}\text { Cerebrovascu- } \\
\text { lar disease }\end{array}$ & LBBB \\
\hline 22 & 73 & Syncope & $\mathrm{Nil}$ & Normal \\
\hline 23 & 72 & Syncope 3 years & $\begin{array}{l}\text { Coronary } \\
\text { artery disease }\end{array}$ & $e^{\text {Left axis }}$ \\
\hline
\end{tabular}

prolongation obtained, expressed as a percentage of the resting RR interval, was $127 \pm 30$ per cent. In one patient, asystole of 4.6 seconds was produced on one occasion only.

\section{(2) SYMPTOMATIC GROUP}

In the 23 symptomatic patients (Table 1), carotid sinus massage produced asystole lasting longer than three seconds in association with cerebral symptoms. The standard electrocardiograms were normal in 12 patients; in the remaining 11, two showed periods of sinuatrial block: one of these patients also had intermittent atrial fibrillation and one had persistent left bundle-branch block.

Electrophysiological investigation of 10 patients (cases 1 to 10, Table 1) showed that five patients with normal resting electrocardiograms had normal sinus node function with conduction times, the only abnormality being an abnormal response to carotid sinus massage which was totally abolished by intravenous atropine.

The two patients (cases 2 and 8) with electrocardiographic signs of sinuatrial block showed evidence of gross sinuatrial node dysfunction with post-pacing asystole for 3 and 5.3 seconds followed by a slow junctional escape rhythm. After intravenous atropine, the junctional escape rhythm was preceded by asystole for 2 and 4.9 seconds, but their abnormal response to carotid sinus massage was totally abolished. Three cases with left axis deviation had prolongation of $\mathrm{HV}$ intervals (Table 2).

The 10 patients who underwent electrophysiological tests had cardiac pacemakers implanted; on follow-up (18 months to three years) their symptoms have completely disappeared. The remaining 13 patients (cases 11 to 23), whose symptoms were

Table 2 Results during electrophysiological study: intervals in milliseconds

\begin{tabular}{|c|c|c|c|c|c|c|c|c|}
\hline \multirow[b]{2}{*}{ Case no. } & \multicolumn{4}{|c|}{ Before atropine } & \multicolumn{4}{|c|}{ After atropine } \\
\hline & $\boldsymbol{R} R$ & $H V$ & CSNRT & $C S M r r$ & $R R$ & $H V$ & CSNRT & $C S M r r$ \\
\hline $\begin{array}{l}3 \\
4 \\
5 \\
6 \\
7 \\
8\end{array}$ & $\begin{array}{r}930 \\
990 \\
1005 \\
950 \\
910 \\
1020\end{array}$ & $\begin{array}{l}45 \\
55 \\
60 \\
55 \\
45 \\
35\end{array}$ & $\begin{array}{r}180 \\
0 \\
150 \\
320 \\
35 \\
3050 \\
\text { JER }\end{array}$ & $\begin{array}{l}7950 \\
3460 \\
3050 \\
4260 \\
7850 \\
3100\end{array}$ & $\begin{array}{l}850 \\
610 \\
910 \\
890 \\
850 \\
810\end{array}$ & $\begin{array}{l}45 \\
55 \\
60 \\
55 \\
45 \\
50\end{array}$ & $\begin{array}{r}160 \\
50 \\
130 \\
300 \\
55 \\
2030 \\
\text { JER }\end{array}$ & $\begin{array}{r}1130 \\
610 \\
920 \\
950 \\
850 \\
820\end{array}$ \\
\hline $\begin{array}{r}9 \\
10\end{array}$ & $\begin{array}{l}830 \\
770\end{array}$ & $\begin{array}{l}75 \\
70\end{array}$ & $\begin{array}{r}270 \\
50\end{array}$ & $\begin{array}{l}3490 \\
3150\end{array}$ & $\begin{array}{l}590 \\
620\end{array}$ & $\begin{array}{l}75 \\
75\end{array}$ & $\begin{array}{r}205 \\
10\end{array}$ & $\begin{array}{l}590 \\
640\end{array}$ \\
\hline
\end{tabular}

HV, conduction time His-Purkinje system (normal 35 to $55 \mathrm{~ms}$ ); CSNRT, corrected sinus node recovery time (normal $<525 \mathrm{~ms}$ ); CSM, carotid sinus massage (normal $<3000 \mathrm{~ms}$ ); JER, junctional escape rhythm. 
mild and infrequent, did not receive pacemakers and their symptoms persisted.

\section{Discussion}

Hypersensitivity of the carotid sinus reflex has long been recognised to be associated with spontaneous syncope. The carotid sinus syndrome is a term reserved for symptomatic patients who have an abnormal response to carotid sinus massage (Weiss and Baker, 1933; Ferris et al., 1935). Several investigators have shown that, in an asymptomatic population, a significant number of people will show severe bradycardia on carotid sinus massage (Purks, 1939; Heidorn and McNamara, 1956; Sigler, 1963). The prevalence of an abnormal response appears to vary according to the duration of the pressure of stimulus applied to the carotid sinus. Thus, in 25 per cent of normal subjects, massage for 30 seconds produced asystole, with or without symptoms (Heidorn and McNamara, 1956).

Massage for 12 seconds in patients with ischaemic heart disease often produced severe bradycardia (Purks, 1939). Because of this high incidence, we have used a shorter period of massage, believing this to be perhaps more akin to the clinical problem and knowing that prolonged massage may be hazardous (Goldenberger, 1963). It is impossible to get a truly standardised stimulus. However, carotid sinus massage was performed by one person only and, using this method, an abnormal response in the control group of patients in hospital was rare $(2 \%)$. The 23 patients gathered from a general medical outpatient clinic complained of syncope, transient amnesia, light headedness, or vertigo. Several patients had been severely symptomatic for many years and five had been misdiagnosed as having epilepsy. Six patients volunteered that they had suffered from transient attacks of amnesia: case 7 could not remember playing a golf shot, and case 3, a garage mechanic, was frequently unable to recall what he had done after servicing cars in the garage pit. The other patients presented with syncope and less specific complaints, such as dizziness, light headedness, or vertigo. In cases 3 and 7 , rotation or extension of the neck invariably produced symptomatic bradycardia.

In case 2, symptomatic bradycardia could be produced repeatedly when swallowing a glass of cold water. In other patients, such a clear association was not seen. However, carotid sinus massage reproduced symptomatic bradycardia in all patients and a high degree of vagal tone or responsiveness may have been responsible for their spontaneous symptoms.
Monitoring was performed in three ambulant patients, but episodic profound sinus bradycardia was observed in all cases. In the two patients (cases 2 and 8 ) who showed both carotid hypersensitivity and impaired sinus node automaticity it was possible to show that these were entirely separate phenomena by the use of atropine, though in the clinical situation these abnormalities may well have had an additive effect in the production of symptomatic bradycardia. It can be argued that by only estimating sinus node recovery time we are not excluding the presence of sinus node disease in the other eight patients studied (Gupta et al., 1974) and that estimation of sinuatrial conduction time, as described by Strauss et al. (1973) or Narula et al. (1978), would have led to the identification of lesser degrees of sinus node disease. We do not believe that this is so or even relevant in patients with such profound symptomatic bradycardia related to excessive vagal responsiveness.

The estimation of sinuatrial recovery and conduction by electrophysiological methods has limited value, and we agree with Evans et al. (1978) that from the practical point of view the diagnosis of sick sinus syndrome is best made from the resting electrocardiogram together with ambulatory monitoring.

Before the widespread use of cardiac pacemakers for the treatment of bradycardia, the carotid sinus syndrome was treated by drugs such as atropine, amphetamines, ephedrine, or by irradiation or denervation of the carotid sinus (Thomas, 1969). Clearly, the most reliable method of treatment in such patients should be cardiac pacing. Until recently there have been isolated reports concerning the role of pacing in this condition.

More recent studies have reported the effect of pacing on carotid hypersensitivity often in association with episodes of complete atrioventricular dissociation (Voss and Magnin, 1970; Bahl et al., 1971 ; Peretz et al., 1973; Walter et al., 1978).

In conclusion, our findings show that hypersensitivity of the carotid sinus reflex is present in a group of patients presenting with transient cerebral disturbances. There may, in addition, be intraventricular conduction disturbance or sinus node disease. However, some patients with severe symptoms may have a grossly abnormal response to carotid sinus massage in the presence of normal electrophysiology. Increased vagal tone or responsiveness as shown by our group of patients seems to be a relatively common mechanism in the production of symptoms in patients presenting to a general medical clinic. Further study is needed to determine the true prevalence of syncope in association with carotid sinus hypersensitivity. The 
technique of carotid sinus massage, as described, is simple and safe; we consider it worth while to include this procedure in the routine examination of patients who have a history of syncope.

\section{References}

Abdon, N. J., and Malmcrona, R. (1975). High pacemaker implantation rate following 'cardiac neurology'. Acta Medica Scandinavica, 198, 455-461.

Bahl, O. P., Ferguson, T. B., and Oliver, G. C. (1971). Treatment of carotid sinus syncope with demand pacemaker. Chest, 59, 262-265.

British Medical fournal (1976). Or in the heart or in the head? 2, 1158.

Evans, T. R., Callowhill, E. A., and Krikler, D. M. (1978). Clinical value of tests of sino atrial function. Pace, 1, $2-7$.

Ferris, E. B., jun, Capps, R. B., and Weiss, S. (1935). Carotid sinus syncope and its bearing on the mechanism of the unconscious state and convulsions. Medicine, 14, 377-456.

Goldenberger, E. (1963). Death following carotid sinus pressure. American fournal of Cardiology, 11, 129.

Gupta, P. K., Lichstein, E., Chadda, K. D., and Badui, E. (1974). Appraisal of sinus node recovery time in patients with sick sinus syndrome. American fournal of Cardiology, 34, 265-270.

Heidorn, G. H., and McNamara, A. P. (1956). Effect of carotid sinus stimulation on the electrocardiograms of clinically normal individuals. Circulation, 14, 11041113.

Narula, O. S., Samet, M. D., and Javier, M. D. (1972). Significance of sinus node recovery time. Circulation, 45, 140-158.

Narula, O. S., Shantha, N., Vasquez, M., Towne, W. D., and Linhart, J. W. (1978). A new method for measurement of sino-atrial conduction time. Circulation, 58, 706-714.
Peretz, D. I., Gerein, A. N., and Miyagishima, R. T. (1973). Permanent demand pacing for hypersensitive carotid sinus syndrome. Canadian Medical Association fournal, 108, 1131-1134.

Purks, W. K. (1939). Electrocardiographic findings following carotid sinus stimulation. Annals of Internal Medicine, 13, 270-279.

Rosenbaum, M. B. (1970). The hemiblocks: diagnostic criteria and clinical significance. Modern Concepts of Cardiovascular Disease, 39, 141-146.

Scarpa, W. J. (1976). The sick sinus syndrome. American Heart fournal, 92, 648-660.

Sigler, L. H. (1963). The cardioinhibitory carotid sinus reflex. Its importance as a vagocardiosensitivity test. American fournal of Cardiology, 12, 175-183.

Strauss, H. C., Saroff, A. L., Bigger, J. T., jun, and Giardina, E. G. V. (1973). Premature atrial stimulation as a key to the understanding of sino atrial conduction in man. Circulation, 47, 86-93.

Thomas, J. E. (1969). Hyperactive carotid sinus reflex and carotid sinus syncope. Mayo Clinic Proceedings, 44, 127-139.

Thormann, J., and Schwartz, F. (1975). Vagal role and pacemaker indication in hypersensitive carotid sinus reflex. European fournal of Cardiology, 3, 47-51.

Voss, D. M., and Magnin, G. E. (1970). Demand pacing and carotid sinus syncope. American Heart fournal, 79, 544-547.

Walter, P. T., Crawley, I. S., and Dorney, E. R. (1978). Carotid sinus hypersensitivity and syncope. American Journal of Cardiology, 42, 396-403.

Weiss, S., and Baker, J. P. (1933). The carotid sinus reflex in health and disease. Medicine, 12, 297-354.

Requests for reprints to Dr A. B. Davies, National Heart Hospital, Westmoreland Street, London W1M 8BA. 